\title{
Effects of age, and protein malnutrition followed by a balanced diet on the non-parallel change in digestive enzymes in the pancreas and their secretion in the rat
}

\author{
BY JOSIANE PROST, JACQUES BELLEVILLE* \\ AND CAROLE VALANTIN-ROLLET \\ Université de Bourgogne, Laboratoire de Physiologie de la Nutrition, Faculté des \\ Sciences Mirande, BP $138-21004$ Dijon Cedex, France
}

(Received 18 November 1987 - Accepted 29 June 1988)

\begin{abstract}
1. Ninety male Wistar rats were divided into two groups. A control group (C) was fed on a balanced diet, containing $200 \mathrm{~g}$ protein $/ \mathrm{kg}$ for $51 \mathrm{~d}$. An experimental group (E) was fed on a low-protein diet containing $50 \mathrm{~g}$ protein $/ \mathrm{kg}$ for $28 \mathrm{~d}$ (PM), and then on a balanced diet for $23 \mathrm{~d}$ (BR). At different days of PM and BR, the pancreas and the pancreatic juice were collected $40 \mathrm{~min}$ after injection of $0.1 \mathrm{mCi}\left[{ }^{3} \mathrm{H}\right]$ leucine. The amounts of amylase $(E C$ 3.2.1.1), trypsinogen 2 (EC 3.4.21.4), chymotrypsinogen 1 (EC 3.4.21.1) and lipase (EC 3.1.1.3) were determined after separation by the isoelectric focussing technique. Incorporation of $\left[{ }^{3} \mathrm{H}\right]$ leucine into the four hydrolases of pancreatic juice and pancreas was also determined.

2. In control rats a progressive increase in the concentration of digestive enzymes and the amounts secreted were observed with age. Maturation was reached when the rats were 9 weeks old. In rats E, PM inhibited maturation of the pancreas. However, individual enzymes were not affected to the same extent and at the same time. As soon as re-feeding was initiated, pancreas maturation took place and a significant increase in these variables was observed. The increases varied according to the hydrolase and did not appear at the same time.

3. In control rats, a preferential secretion of newly synthesized enzymes was observed in young rats, whereas with age, the proportion of newly synthesized enzymes excreted decreased slowly. In group $E$ rats, at the beginning of PM, the proportion of newly synthesized enzymes secreted was very low and increased with time.

4. In rats $C$ and $E$, our results indicated a non-parallelism between pancreatic enzyme levels and amounts secreted. This non-parallelism was different in both groups, it was changed with age and pancreas maturation in group $\mathrm{C}$, and according to nutritional state in group $\mathrm{E}$.
\end{abstract}

Two conflicting hypotheses about exocrine pancreatic secretion can be found in the literature. The parallel hypothesis, chiefly supported by Jamieson \& Palade (1971), Scheele \& Palade (1975) and Palade (1975), states that the concentration of one enzyme secreted by the pancreas will be related to the constant amount of that enzyme in the pancreatic tissue. The non-parallel or enzyme-specific hypothesis, supported by Adelson \& Rothman (1974), Rothman \& Isenman (1974), Dagorn et al (1977a, b), Robberecht et al. (1977) and Dagorn (1978), stipulates a non-parallel change in the proportions of the different enzymes in the pancreas and pancreatic juice after administration of certain hormones, neurotransmitters, metabolites or digestive stimuli to various whole pancreatic preparations, both in vitro and in vivo. However, these contradictory findings have been obtained with different species, ages, types of stimulation and different technical approaches. Furthermore, the measurement of enzyme activities in the pancreas and pancreatic juice has never been carried out in vivo in the same animal. Our previous findings for the proteindeprived rat (Kheroua \& Belleville, 1981; Prost et al. 1982, 1983) provide evidence for nonparallel variations in enzyme activities in the pancreas and pancreatic juice during protein malnutrition, followed by a balanced diet. However, in our studies, the interpretation of results was difficult because we measured enzyme activities in pancreas and in pancreatic juice originating from different rats. Moreover, the determination of activities raises the problem of optimal zymogen activation and also the control of pancreatic components

\footnotetext{
* For reprints.
} 
which could activate or inhibit enzyme activities. This led us to determine, by the isolectric focussing technique (IEF), enzyme levels in the pancreas and pancreatic juice in the same rats. Enzyme levels and changes were therefore determined relative to age in control rats, and in experimental rats given a low-protein diet followed by balanced re-feeding.

We have studied four pancreatic digestive hydrolases : amylase (EC 3.2.1.1), trypsinogen 2 (EC 3.4.21.4), chymotrypsinogen 1 (EC 3.4.21.1) and lipase ( $E C$ 3.1.1.3), which represent about $50 \%$ of the total digestive enzymes of the pancreas and pancreatic juice. We used growing rats. The respective test meals were given by gastric intubation.

In the present paper we show that enzyme levels in the pancreas and pancreatic juice change in a non-parallel manner. We have defined the retention threshold as the value of the ratio of pancreas level of one enzyme to the output of the same enzyme in pancreatic juice. Our results provide evidence for variations of retention threshold in acinar cells, depending on age and on the time of protein deficiency followed by re-feeding a balanced diet.

\section{MATERIALS AND METHODS \\ Rats and diets}

Ninety male Wistar rats (Iffa-Credo, Lyon), weighing 98 (SE 4) $g$ at the beginning of experiment, were allowed free access to a balanced diet containing $200 \mathrm{~g}$ protein $/ \mathrm{kg}$ (gluten : casein, 160:40, w/w) for $10 \mathrm{~d}$. After this adaptation period, they were divided into two equal groups, their mean weight being 120 (SE 10) $\mathrm{g}$.

A control group (C) was maintained on the balanced diet for a further $51 \mathrm{~d}$. An experimental group (E) was fed on a low-protein diet containing $50 \mathrm{~g}$ protein $/ \mathrm{kg}$ (gluten : casein, $40: 10, \mathrm{w} / \mathrm{w}$ ) for $28 \mathrm{~d}$ (protein-malnutrition phase, $\mathrm{PM}$ ), and was then fed on the balanced diet for $23 \mathrm{~d}$ (balanced-re-feeding phase, BR). The compositions of the diets are shown in Table 1 ; the diets were isoenergetic. Food and water were supplied $a d$ lib. Rats were housed individually in stainless-steel cages at $25^{\circ}$ and light was provided for $12 \mathrm{~h} / \mathrm{d}$.

\section{Nitrogen balance}

For fifteen rats from each group, daily food intakes and body-weights were measured, and apparent digestibility of $\mathrm{N}(\mathrm{N}$ ingested $-\mathrm{N}$ excreted $/ \mathrm{N}$ ingested $\times 100), \% \mathrm{~N}$ retention $(\mathrm{N}$ ingested $-\mathrm{N}$ faecal $/ \mathrm{N}$ ingested $\times 100$ ) and protein efficiency ratios (gain of body-weight/ protein intake to obtain this gain) were determined for periods of 1 week. Faeces and urines were accumulated for each weekly period. The $\mathbf{N}$ contents of faeces, urine and diet were estimated by the micro-Kjeldahl method.

\section{Pancreatic juice and pancreatic extract samples}

At days 2, 9, 16 and 23 of PM and days 2, 9 and 23 of BR, five rats from each group were anaesthetized with Imalgene (Iffa-Merieux, Lyon) and fitted with a double pancreatic and biliary cannula to obtain pure pancreatic juice. After $24 \mathrm{~h}$, each rat received its respective diet (about $1 \mathrm{~g}$ homogenized in $1 \mathrm{ml}$ water) by gastric intubation and $2 \mathrm{~h}$ later $\left(t_{0}\right)$, received, in a single intravenous injection, $0 \cdot 1 \mathrm{mCi} \mathrm{L}-\left[3,4,5-{ }^{3} \mathrm{H}\right]$ leucine (CEA, Gif sur Yvette) (specific radioactivity $0.72 \mathrm{Ci} / \mathrm{mmol}$ ) in $0.5 \mathrm{ml} 0.15 \mathrm{M}$-sodium chloride. Pancreatic juice was collected for two $20 \mathrm{~min}$ periods $\left(t_{0-20}\right.$ and $\left.t_{20-40}\right)$ because $40 \mathrm{~min}$ after $\left[{ }^{3} \mathrm{H}\right]$ leucine injection, the specific radioactivity (SRA) of the enzymes in the pancreas peaked and decreased afterwards. The pancreas was then rapidly removed to obtain pancreatic extracts.

\section{Analytical methods}

The pancreas was washed with cold saline $(9 \mathrm{~g} \mathrm{NaCl} / 1)$, freed from extraneous tissue and fat, and weighed. Pancreatic tissue was homogenized in 10 vol. ice-cold distilled water, at 
Table 1. Composition $(\mathrm{g} / \mathrm{kg})$ of the experimental diets given to rats

\begin{tabular}{|c|c|c|c|c|c|c|}
\hline \multirow{2}{*}{$\begin{array}{l}\text { Diet... } \\
\text { Ingredients }\end{array}$} & \multicolumn{3}{|c|}{ Control } & \multicolumn{3}{|c|}{ Low-protein } \\
\hline & $\mathrm{g} / \mathrm{kg}$ & $\begin{array}{c}\% \text { of } \\
\text { energy }\end{array}$ & $\mathrm{kJ} / \mathrm{kg}$ & $\mathrm{g} / \mathrm{kg}$ & $\begin{array}{c}\% \text { of } \\
\text { energy }\end{array}$ & $\mathrm{kJ} / \mathrm{kg}$ \\
\hline Casein* & 40 & 4 & 680 & 10 & 1 & 170 \\
\hline Wheat gluten $\uparrow$ & 160 & 16 & 2700 & 40 & 4 & 680 \\
\hline Wheat starch* & 590 & 61 & 9980 & 730 & 76 & 12340 \\
\hline Sucrose* & 40 & 4 & 680 & 50 & 5 & 840 \\
\hline Groundnut oil $\ddagger$ & 60 & 14 & 2280 & 60 & 14 & 2280 \\
\hline Agar-agar (fibres*) & 50 & 0 & 0 & 50 & 0 & 0 \\
\hline Salt mixtures $\S$ & 40 & 0 & 0 & 40 & 0 & 0 \\
\hline Vitamin mixture & 20 & 0 & 0 & 20 & 0 & 0 \\
\hline
\end{tabular}

The diets were semi-synthetic and isoenergetic $(16320 \mathrm{~kJ} / \mathrm{kg}$ diet $)$ and given as a powder.

* Prolabo; Paris.

+ L. François; Saint Maur les Fossés.

$\ddagger$ Commercial product.

$\S$ UAR; Epinay sur Orge. The salt mixture provided the following amounts (g/ $\mathrm{kg} \mathrm{diet)}$ : calcium 4, potassium $2 \cdot 4$, sodium 1.6 , magnésium 0.4 , iron 0.12 , trace elements, manganese 0.032 , copper $0 \cdot 005$, zinc 0.018 , cobalt 0.00004 , iodine 0.0002 .

T The UAR 200 vitamin mixture provided the following amounts ( $\mathrm{mg} / \mathrm{kg} \mathrm{diet}$ ): thiamin 40 , riboflavin 30 , nicotinic acid 140 , pyridoxine 20 , pyridoxal 300 , cyanocolabamin $0 \cdot 1$, ascorbic acid 1600 , tocopherol 340 , menadione 80 , calcium pantothenate 200 , choline 2720 , folic acid 10 , p-aminobenzoic acid 100 , biotin $0 \cdot 6$, retinol 12, cholecalciferol $0 \cdot 125$.

$1500 \mathrm{rpm} / \mathrm{min}$ for two $30 \mathrm{~s}$ periods using a Potter Elvejhem homogenizer. Tissue homogenates were centrifuged at $100000 \mathrm{~g}$ for $45 \mathrm{~min}$ at $4^{\circ}$ using a Beckman $\mathrm{L} 565$ ultracentrifuge equipped with rotor $65 \mathrm{Ti}$. The supernatant fraction was divided into $1 \mathrm{ml}$ portions and kept at $-40^{\circ}$. Protein in each pancreatic extract and pancreatic juice sample was assayed according to Lowry et al. (1951). Radioactivity of total proteins or specific enzyrnes was measured by liquid scintillation using a Tri Carb 300 CD Packard scintillation counter.

For each pancreatic juice and extract sample, the enzymes were separated by IEF. This technique allows the separation of proteins according to their isoelectric point (pI). An agarose IEF gel (Pharmacia, Uppsala, Sweden) with a gradient of pH 3-10 (Ampholytes 3-10, Pharmacia) was used for enzyme separation of pancreatic juice samples. This separation required a supplementary step for pancreatic extract samples in a gradient of $\mathrm{pH}$ 4 6.5 (Ampholytes 4-6.5, Pharmacia) because structural and serum proteins were observed with a pI set between $\mathrm{pH} 4$ and 6.5. Electrophoresis was run for $90 \mathrm{~min}$ at $11^{\circ}$ with 1500 $\mathrm{V}$ and $6 \mathrm{~mA}$.

Precipitation and fixation of the enzymes within the agarose gel were achieved by immersion in a solution of sulphosalicylic acid $(50 \mathrm{~g} / \mathrm{l})$ and trichloroacetic acid $(100 \mathrm{~g} / \mathrm{l})$ for $30 \mathrm{~min}$. The gels were placed for $90 \mathrm{~min}$ in an acetic acid-ethanol-water solution $(10: 35: 55$, by vol.), which is a destaining solution, to elute peptides and free amino acids. The gels were stained for $10 \mathrm{~min}$ in coomassie brilliant blue R250 solution $(2 \mathrm{~g} / 1$ destaining solution). The gels were then destained. Duplicate samples of each pancreatic juice and pancreatic extract were subjected to IEF. One IEF band was used, after staining, for the determination of the relative protein contents of the four hydrolases by densitometric scans carried out at $600 \mathrm{~nm}$ using a Cellomatic densitometer (Sébia, Issy les Moulineaux).

To estimate the amounts of each enzyme, the percentage of the area relative to each enzyme was multiplied by the total protein of each sample. These results were expressed as 
arbitrary units (AU). The protein mass of the enzyme was not reflected by enzyme coloration on IEF bands because all proteins do not ligate an equal number of molecules of coomassie blue on a unit weight basis. However, we can state that for one given enzyme the evaluation in the different samples was the same. Moreover, when 50-200 $\mu \mathrm{g}$ total protein were applied, the chromogenicity of each major band varied linearly with the amount of total proteins applied on the gel. Furthermore, pancreatic juice and extract samples from the two dietary groups (C and $\mathrm{E}$ ) were always subjected to IEF in parallel. Each enzyme showed a single stain. The four selected enzymes were represented by five spots (two spots for amylase).

Three trypsinogens and two chymotrysinogens have been observed in pancreatic juice and extract samples from the rat (Marchis Mouren, 1965; Watanabe et al. 1980). However, we only studied the behaviour of trypsinogen 2 and chymotrypsinsogen 1 because they represent about $80-90 \%$ of the total trypsic and chymotrypsic activities of pancreatic juice. The duplicate IEF band was used for the determination of the relative levels of radioactivity in these enzymes by liquid scintillation counting. Bands corresponding to amylase, trypsinogen 2, chymotrypsinogen 1 and lipase were sliced and removed, digested with $0.25 \mathrm{ml}$ Soluene 350 (Packard) and $0.1 \mathrm{ml}$ water and then $7 \mathrm{ml}$ Xylene-Permafluor III scintillant (Packard) added for determination of radioactivity according to Moore (1980).

Plate 1 shows typical IEF bands for pancreatic juice and extract samples, with the site and focussing isoelectric point of each hydrolase. The localization of the enzymes in the IEF bands was obtained by a zymogram technique according to Uriel (1971) and by measuring the hydrolytic activity of each IEF band containing the enzyme for a specific substrate. The trypsinogens and chymotrypsinogens were activated by incubating the pieces of IEF band with enterokinase (EC 3.4.21.9) for trypsinogen 2 and trypsin for chymotrypsinogen 1 . Trypsin and chymotrypsin activities were determined according to Figarella et al. (1965) using the synthetic substrates $n$-benzoyl-arginine ethyl ester (Fluka) for trypsin activity and $n$-arginine-tyrosyl ethyl ester (Fluka) for chymotrypsin activity. Lipase activity was measured according to Borgström \& Hildebrand (1975), using tributyrin (Merck) as the substrate without bile salt to measure potential lipase activity unrelated to the colipase level in the sample. Amylase activity was determinated according to Street \& Close (1956), using amylose (Merck) as substrate.

\section{Statistics}

Results are expressed as the arithemetical mean of each group with their standard errors. The significance of the difference between mean values was obtained by Student's $t$ test for paired samples and analysis of variance. Differences were considered statistically significant at $P<0.05$.

\section{RESULTS}

In the present study, the effects of pure PM were investigated since food intake was higher per $\mathrm{kg}$ body-weight in group $\mathrm{E}$ rats than in group $\mathrm{C}$ rats. Food intake decreased from 112 to $52 \mathrm{~g} / \mathrm{kg}$ body-weight from the beginning to the end of the experiment in group $\mathrm{C}$ rats, as the requirements for growth decreased with age. In group $\mathrm{E}$ rats these values changed from 117 to $99 \mathrm{~g} / \mathrm{kg}$ body-weight with PM, then decreased from 99 to $66 \mathrm{~g} / \mathrm{kg}$ body-weight with BR. The most obvious consequence of PM was a significant slowing down of growth. The weight of group E rats represented only $58 \%$ of the control values after $23 \mathrm{~d}$ of PM. BR allowed a rapid recovery of growth but a deficit was still observed after $23 \mathrm{~d}$ of $\mathrm{BR}$ $(17 \%)$. The findings presented in Table 2 indicate that apparent digestibility of $\mathrm{N}$ remained 
Protein malnutrition and pancreatic hydrolases

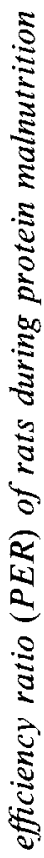

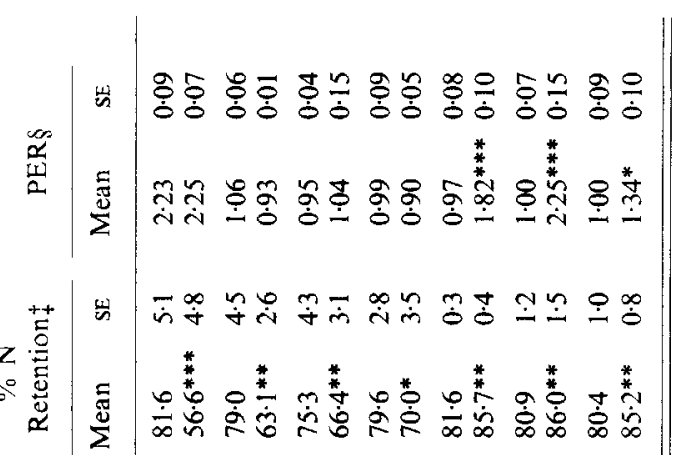

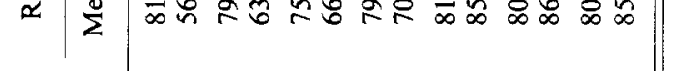

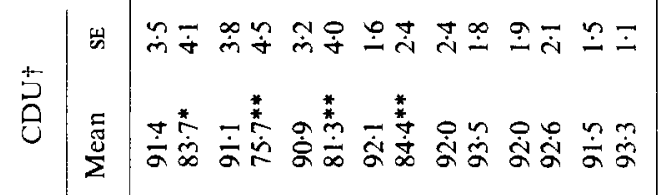

:

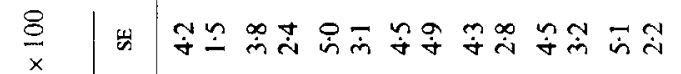

昜

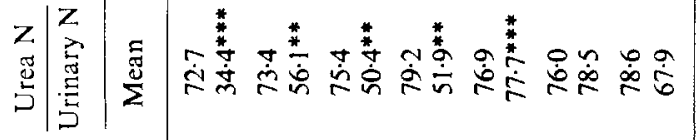

$\exists \dot{0}$

is

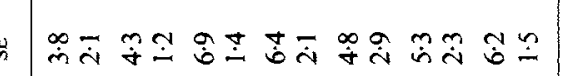

कू

要*

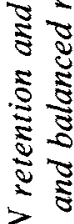

$z \sum_{0}^{\infty}$

Z妾昰

可

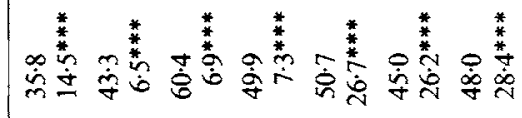

ह

S

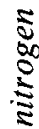

8

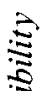

$\overbrace{0}^{\infty}$

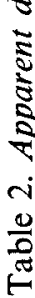

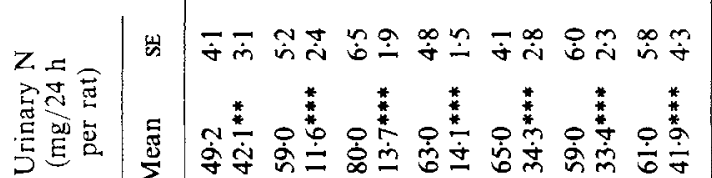

水*

㐔

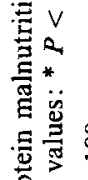

Z

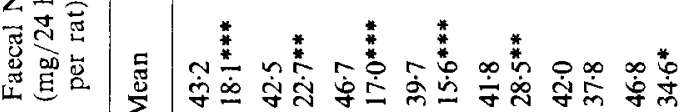

on $\frac{z}{\sqrt{2}}$

동

ह 1

焉总

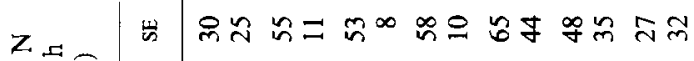

要党

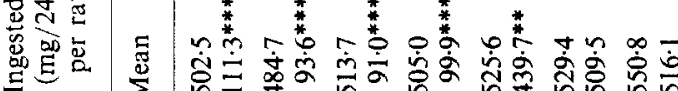

焉密

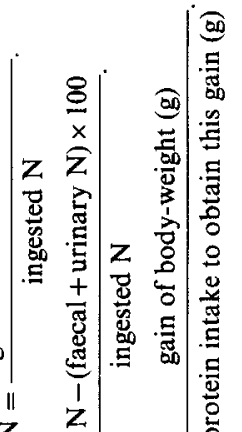

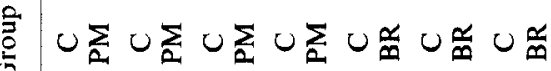

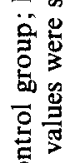

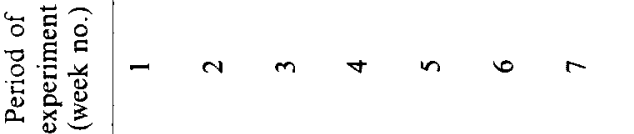




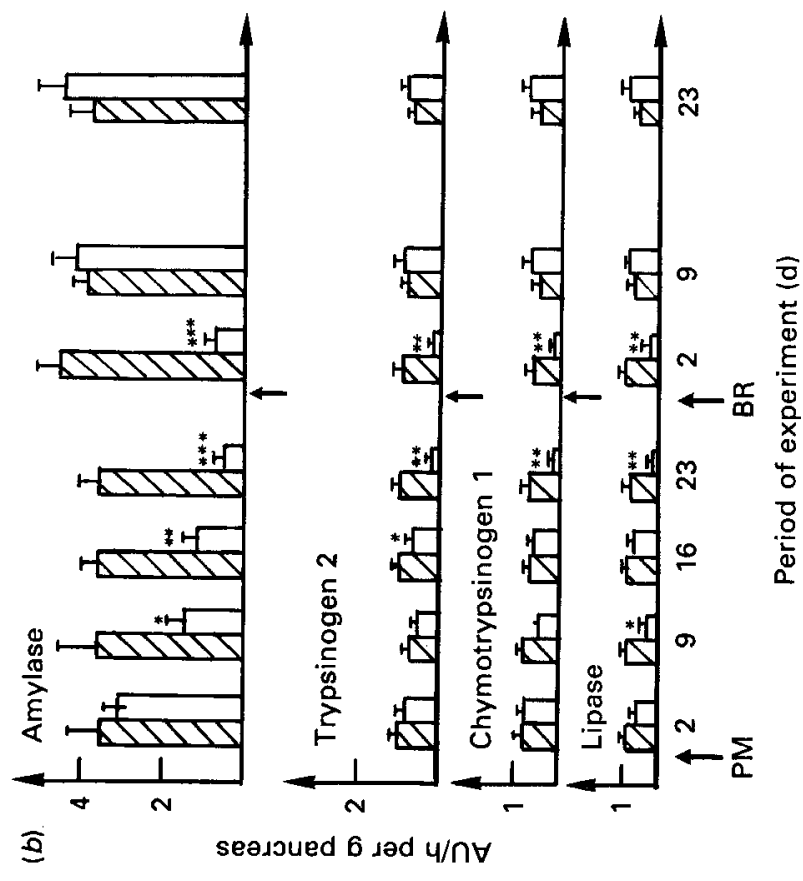

홀

解记

通

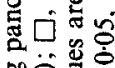

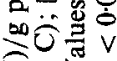

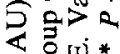

通事

品产产

를

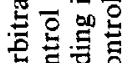

更递

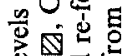

政

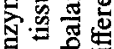

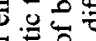

동

政.

8 an 8

要空

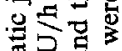

娄

需

on

费悹总

跑品

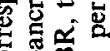

送要

它范

$\therefore 8$.

品昆

하음 등

\%

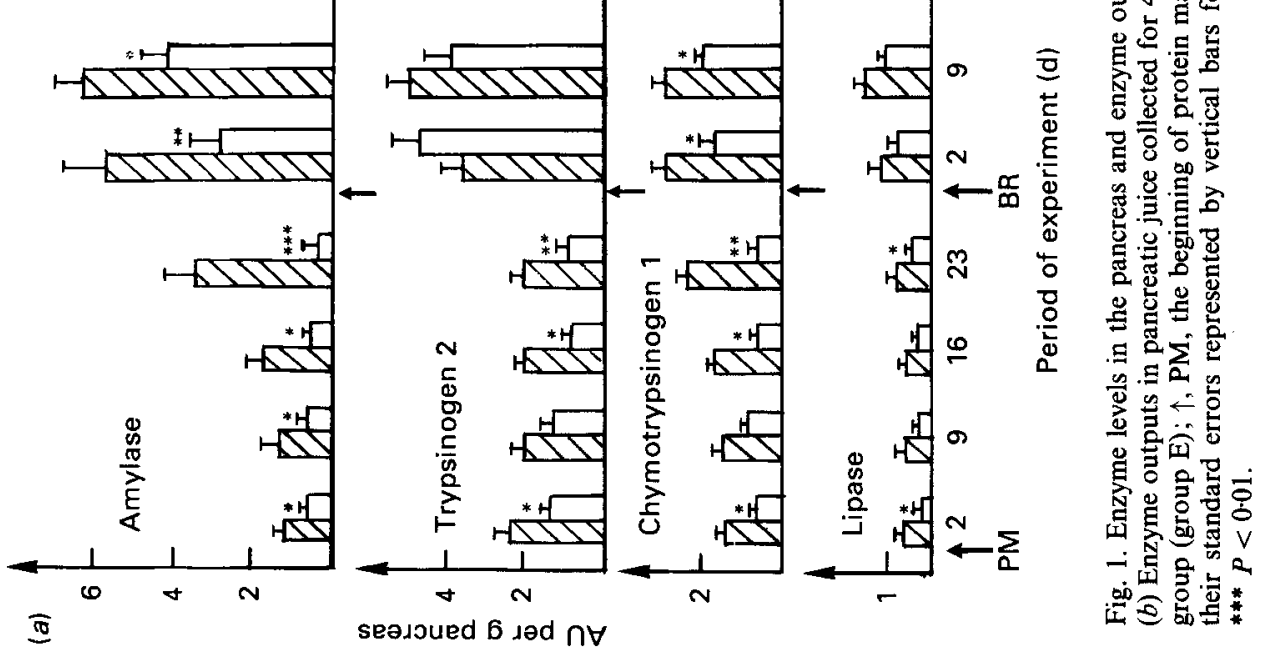




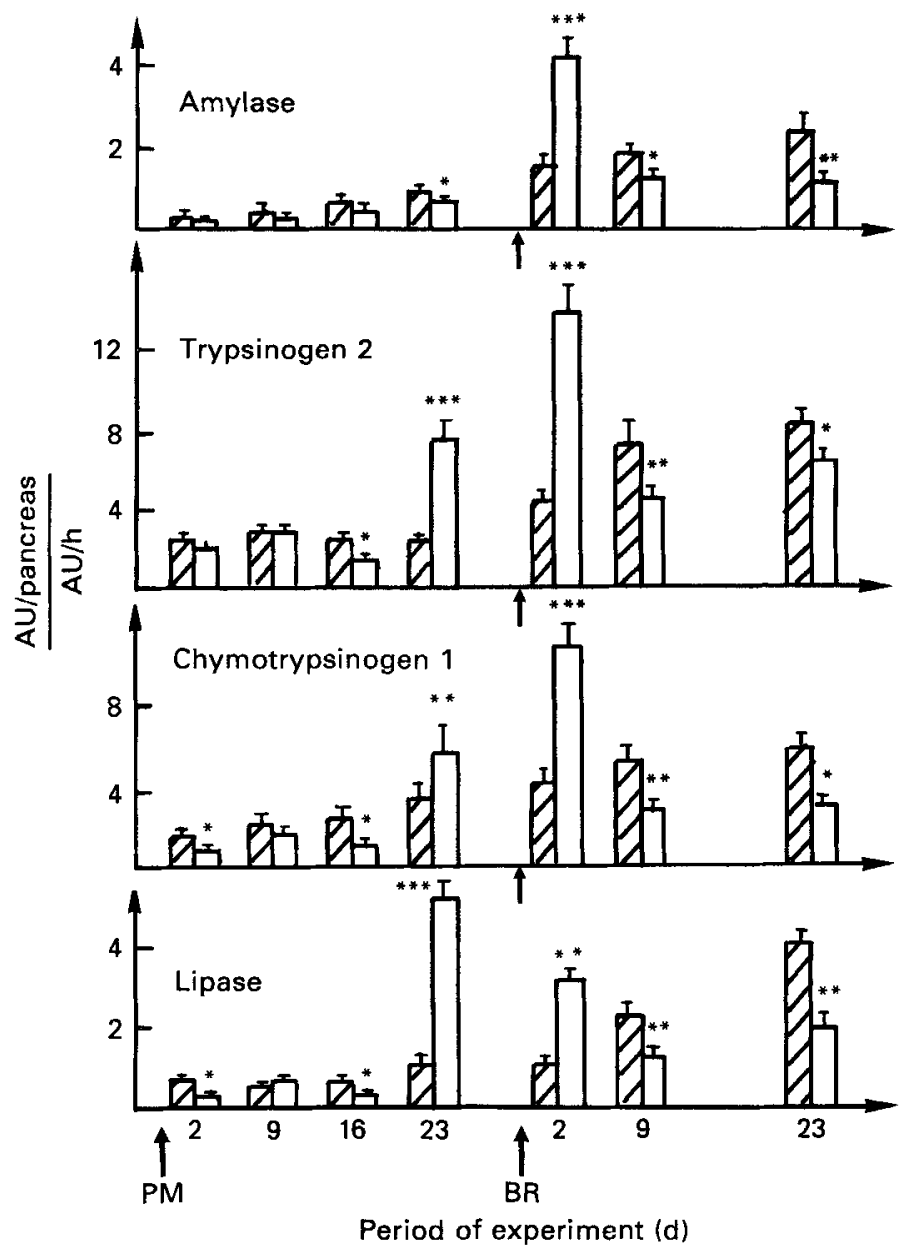

Fig. 2. A comparison of the amount of a specific enzyme (arbitrary units; AU) in the pancreas and its output in corresponding pancreatic juice.

AU of one enzyme/pancreas

\section{$\mathrm{AU} / \mathrm{h}$ of the same enzyme in the corresponding pancreatic juice.}

$\square$, Control group (group C); $\square$, experimental group (group E); $\uparrow$ PM, the beginning of protein malnutrition; $\uparrow \mathbf{B R}$, the end of $\mathbf{P M}$ and the beginning of balanced re-feeding in group $\mathrm{E}$. Values are means with their standard errors represented by vertical bars for five animals per group. Means were significantly different from control values: ${ }^{*} P<0.05,{ }^{* *} P<0.02,{ }^{* * *} P<0.01$.

constant over the 7-week period $(0.909-0.920)$ for group $\mathrm{C}$ rats while it varied from 0.757 to 0.844 for group E rats during PM and remained unchanged with BR (0.926-0.936). N retention (\%) was constant in group $\mathrm{C}$ rats (mean 79.8 (SE 2.5)\%) throughout the experiment, increased from 56.6 to $70.0 \%$ during PM for group E rats and was stable during BR (mean 85.6 (SE 0.8) \%). With the PM diet, protein efficiency ratios were similar in both groups. In contrast, during re-feeding, the values for group $E$ rats were higher than those for group $\mathrm{C}$ rats, especially at the beginning of $\mathrm{BR}$.

Fig. 1 shows the amounts of four hydrolases studied in pancreatic extracts (expressed as $\mathrm{AU} / \mathrm{g}$ pancreatic tissue) and the outputs in pancreatic juice (expressed as $\mathrm{AU} / \mathrm{h}$ per $\mathrm{g}$ pancreas). For group C, amylase, trypsinogen 2, chymotrypsinogen 1 and lipase levels 


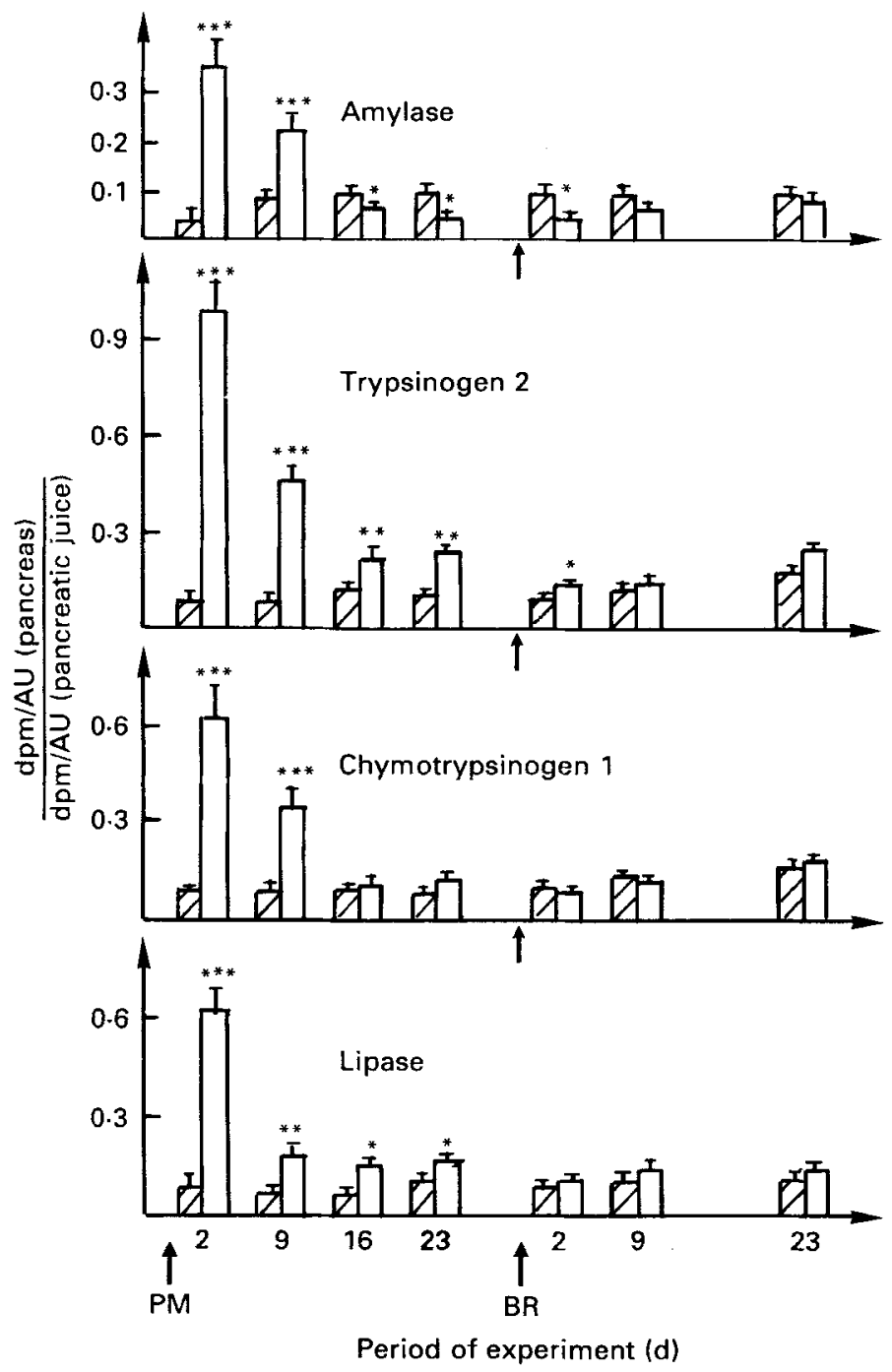

Fig. 3. A comparison of the specific radioactivity (SRA; disintegrations/min per amount of enzyme (arbitrary units; AU)) of an enzyme in the pancreas and its SRA in the corresponding pancreatic juice (ratio of SRA in the pancreas: SRA in the pancreatic juice). $\square$, Control group (group C); $\square$, experimental group (group E); $\uparrow$ PM, the beginning of protein malnutrition; $\uparrow \mathrm{BR}$, the end of $\mathrm{PM}$ and the beginning of balanced re-feeding in group $E$. Values are means with their standard errors represented by vertical bars for five animals per group. Means were significantly different from control values: ${ }^{*} P<0.05,{ }^{* *} P<0.02,{ }^{* * *} P<0.01$.

in the pancreas (Fig. $1(a)$ ) increased with age, the higher levels corresponding to days $2-9$ on the BR diet for group E rats. This increase in pancreas enzyme levels was particularly significant for amylase (5.5-fold higher between day 2 of the experiment and day 9 of BR). For group E, enzyme levels decreased slightly during the period of PM and increased quickly at day 2 of BR (8-, 3-, 2-5-, 2-fold for amylase, trypsinogen 2, chymotrypsinogen 1 and lipase respectively compared with values for day 23 of PM). For group $\mathrm{C}$, the enzyme outputs remained constant with age (Fig. 1(b)). For group E, the outputs decreased and for amylase were time-related in the PM period. This was not apparent for the other enzymes. However the outputs for all enzymes had decreased 
proportion of newly synthesized enzymes present in the pancreatic juice, and therefore that secreted. In group $\mathrm{C}$, the levels were unchanged, but the differences between SRA in the pancreas and pancreatic juice were quite high (1:10-1:20 for amylase, 1:4-1:10 for trypsinogen 2 and chymotrypsinogen 1 and $1: 10-1: 5$ for lipase). In group $E$ the values greatly increased after $2 \mathrm{~d}$ of PM (ten-fold compared with group $\mathrm{C}$ values), then decreased during the remaining PM period. During BR, the values fell to group C levels at day 2 of BR for lipase and chymotrypsinogen 1 and at day 9 of BR for amylase and trypsinogen 2 .

Fig. 4 shows a comparison of the relative contents of enzymes in the pancreas (Fig. 4(a)) and in pancreatic juice (Fig. 4(b)). In the pancreas of group C rats (Fig. 4(a)), all relative enzyme contents showed the same pattern of change with age. The highest values were found between day 23 of PM and day 9 of BR, then they decreased at the end of experiment. In group $E$ rats, the three values remained constant during $P M$, but from the beginning of BR these values were twice as high, then remained constant to the end of the experiment. In pancreatic juice (Fig. 4(b)), the values were higher than those in pancreatic extract and revealed non-parallel proportions of these enzymes in the pancreas and its secretion. Except for amylase/chymotrypsinogen 1 values, the group $\mathrm{C}$ values showed a different pattern of change in pancreatic extract and juice. Values for amylase/trypsinogen 2 varied more in the pancreatic juice of group E rats during PM; the amylase/trypsinogen 2 values remained constant, which indicated a parallel course for these latter enzymes. At the beginning of BR, amylase/trypsinogen 2 values increased but amylase/chymotrypsinogen 1 and amylase/lipase values decreased.

\section{DISCUSSION}

The aim of the present study was to determine the effects of a low-protein diet on protein digestibility and on amylase, trypsionogen 2, chymotrypsinogen 1 and lipase levels in pancreas and their outputs in pancreatic juice in the same rat. We also investigated whether a non-parallelism hypothesis could be applied to digestive enzyme levels in pancreas and pancreatic juice in relation to age in group $C$ rats and nutritional state in group $E$ rats. Rats fed on a low-protein diet showed very slow growth. In protein-deficient rats the $\mathrm{N}$ losses via the faeces and urine were lower, but as a proportion of $\mathrm{N}$ ingested were higher, than those of group $\mathrm{C}$ values. $\mathrm{N}$ retention (\%) was improved with the duration of $\mathrm{PM}$ but remained constant. This adaptation to $\mathrm{PM}$ involved an increase in $\mathrm{N}$ apparent digestibility and $\% \mathrm{~N}$ retention, and indicated a better $\mathrm{N}$ utilization during $\mathrm{PM}$. With $\mathrm{BR}, \mathrm{N}$ losses relative to $\mathrm{N}$ intake remained lower in group $\mathrm{E}$ than in group $\mathrm{C}$ rats, as if there were biochemical adjustments to conserve $\mathrm{N}$ during PM, which persisted after PM had ended. Therefore, $\mathrm{N}$ apparent digestibility, $\% \mathrm{~N}$ retention and protein efficiency ratios were higher in $\mathrm{BR}$ rats than in group $\mathrm{C}$ rats (Waterlow, 1975). These phenomena facilitated the recovery of body-weight.

Removal of pancreatic juice from the intestine leads to an increase in secretion. Under physiological conditions in the intestine, free trypsin and chymotrypsin inhibit the secretion of cholescystokinin (CCK). The removal of pancreatic juice prevents the negative feedback effect of these proteases and leads to hypersecretion of this hormone and stimulation of pancreatic secretion and enzyme outputs (Ishe \& Lilja, 1979; Simoes-Nunes et al. 1981). Under our experimental conditions the volume of pancreatic juice and outputs of digestive enzymes became constant $24 \mathrm{~h}$ after catheterization. Moreover, the pancreatic juice and the pancreas were removed in the digestive phase. We also observed that meal intubation was another stimulatory factor of the pancreatic juice output in addition to the pancreatic duct fistula. 
During sampling, the protein and pancreatic juice outputs remained unchanged. This was noted previously by Keim (1986) in the conscious rat. Non-parallelism which occurs between pancreatic juice and pancreatic extract with trypsinogen 2 and chymotrypsinogen 1 could be caused by a non-homogenous activation of these zymogens (Scheele \& Palade, 1975). This problem was prevented in this study by the evaluation of enzyme contents.

Enzyme levels in the pancreas increased with age (Fig. 1(a)), reaching a maximum level in 9-week-old rats. Digestive enzyme synthesis increases with age in the rat, from day 18 of pregnancy to adult age, and accounts for $90 \%$ of the total synthesis of pancreatic proteins (Van Nest et al. 1980). In group E, PM inhibited the pancreatic maturation noted in group $\mathrm{C}$ and appeared delayed during the BR. Several authors have demonstrated that with carbohydrate-rich diets, amylase levels and outputs are increased (Grossman et al. 1942; Howard \& Yudkin, 1963; Wicker et al. 1984). In the present experiment the lowprotein diet was a carbohydrate-rich diet, but we found that amylase amounts and outputs decreased. So a sufficient dietary protein level was an important factor in the adaptation of amylase to a carbohydrate-rich diet. Similar results have been obtained for colipase; the pancreas level decreases when the diet is rich in lipid but protein-deficient (Saraux et al. 1982).

Trypsinogen and chymotrypsinogen levels correlate with protein levels in the diet (MacLeod et al. 1972; Schick et al. 1984). Adaptation of protease levels occurs at the transcriptional level (Wicker et al. 1984; Giorgi et al. 1985). The mechanism by which adaptation occurs, and the molecular events allowing differential regulation of enzyme synthesis in the pancreas, are not fully understood. In our experiment trypsinogen was more sensitive than chymotrypsinogen to PM and their behaviour was non-parallel during the course of PM and BR.

If the levels of enzyme in the pancreas and in pancreatic juice evolved in parallel, the values would be the same and the secretion of a specific enzyme would reflect its synthesis in the pancreas. If the values were different, this would show non-parallelism between the pancreas enzyme level and its secretion. This would suggest that their retention threshold in acinar cells changes. Non-parallel hydrolase levels and outputs (Fig. 2) may be due to changes in intracellular transport or structural alteration of membranes, which might impair the exocytosis processes. Exocytosis depends on gastric duodenal or digestive hormones such as CCK. The secretion of CCK might decrease with the duration of PM as the gut becomes atrophied. BR would then promote restoration of the gut and consequently CCK secretion. Yet the effect of PM on membranes would last longer, which would increase the retention threshold at day 2 of BR. These hormones interact on membrane receptors. Gardner \& Jensen (1980) showed that modifications of the membrane interfered with the CCK action on membrane receptors and with the efficiency of the CCK to stimulate acinar cell secretion. Leung et al. (1986) demonstrated that the capacity of highaffinity CCK receptors in pancreatic acini of rat gradually increased with age. PM could inhibit this maturation of receptors. Moreover, isolated pancreatic lobules of malnourished rats were not activated by CCK (Prost \& Belleville, 1987).

SRA (Fig. 3) values indicated that the radioactivity incorporated into enzymes of pancreatic juice increased more than in pancreatic extract. If synthesis and secretion were parallel, SRA values should be constant for each enzyme. The newly synthesized enzymes (radioactive enzymes), compared with previously synthesized enzymes (non-radioactive enzymes) in pancreatic extract and juice represented 3-6\% in group $C$ and $1-4 \%$ in group E. These low proportions could not interfere with the values obtained in Fig. 2. Control values indicated a preferential secretion of newly synthesized enzymes in young rats, whereas with age, the proportion of newly synthesized enzymes excreted decreased slowly. The proportion of newly synthesized amylase present in pancreatic juice was higher than 
the proportion of trypsinogen 2 , chymotrypsinogen 1 or lipase. In group $\mathrm{E}$, the proportion of newly synthesized enzymes excreted in pancreatic juice at the beginning of PM was very low and increased with the duration of PM. The results (Fig. 3) suggest that the proportion of newly synthesized hydrolases in pancreatic juice increases with the duration of PM. For groups $\mathrm{C}$ and $\mathrm{E}$, during $\mathrm{PM}$, these values change with time and reveal an inverse relation. At the end of PM and at the beginning of re-feeding, these values for group $E$ rats were approximately the same as those for control rats and BR did not modify the proportion of newly synthesized enzymes secreted.

If the variations relative to time or nutritional state in the two enzyme levels are the same, their relative contents in pancreas and pancreatic juice must remain constant; if they do not, the enzymes vary in a non-parallel manner. The results (Fig. 4) demonstrate that the levels of the hydrolases studied varied with age in a non-parallel manner and that the maturation of each pancreas enzyme was different.

The results shown in Fig. 4 compared with those of Fig. 3 allow us to state that the newly synthesized enzyme retention at the beginning of PM is not linked to a higher retention threshold. This is indicative of a more rapid secretion of stored enzymes compared with newly synthesized ones. At the end of PM and at the beginning of BR, the higher retention threshold does not result essentially from a change in secretion of newly synthesized enzyme but from an actual increase in storage abilities. The contents and SRA values undoubtedly indicate non-parallelism between pancreatic levels and pancreatic juice outputs. These results are confirmed by the protein content values for amylase $v$. trypsinogen 2 , chymotrypsinogen 1 or lipase. This non-parallelism was different in both groups, it changed with age and pancreas maturation in group $\mathrm{C}$ rats, and according to nutritional state in group E rats.

The results show, without ambiguity, a non-parallel behaviour of the four enzymes in the pancreas and pancreatic juice which was related to the nature of the diet. However, the variations were less marked in pancreatic juice than in pancreatic extract.

The excellent technical assistance of Marie-Thérèse Divry-Aellen was greatly appreciated. The authors are indebted to Anne Magnet for help with the English language. This work was supported by the Ministry of Education and the Ministry of Research and Industry.

\section{REFERENCES}

Adelson, J. W. \& Rothman, S. S. (1974). Science 183, 1087-1089.

Borgström, B. \& Hildebrand, H. (1975). Scandinavian Journal of Gastroenterology 10, 585-591.

Dagorn, J. C. (1978). Journal of Physiology 280, 435-448.

Dagorn, J. C., Paradis, D. \& Morisset, J. (1977a). Digestion 15, 110-121.

Dagorn, J. C., Sahel, J. \& Sarles, H. (1977b). Gastroenterology 73, 42-45.

Figarella, C., Taulier, J. \& Sarles, H. (1965). Bulletin de la Société de Chimie Biologique 47, 679 686.

Gardner, J. D. \& Jensen, R. T. (1980). American Journal of Physiology 238, G63-G86.

Giorgi, D., Renaud, W., Bernard, J. P. \& Dagorn, J. C. (1985). Biochemical and Biophysical Research Communications 127, 937-942.

Grossman, M. I., Greengard, H. \& Ivy, A. C. (1942). American Journal of Physiology 138, 676682.

Howard, F. \& Yudkin, J. (1963). British Journal of Nutrition 17, 281 -294.

Ishe, I. \& Lilja, P. (1979). Science 204, 1212-1215.

Jamieson, J. D. \& Palade, G. E. (1971). Journal of Cell Biology 50, 135-158.

Keim, V. (1986). Annals of Nutrition and Metabolism 30, 104-112, 113-119.

Kheroua, O. \& Belleville, J. (1981). Reproduction, Nutrition, Développement 21, 901-918.

Leung, Y. K., Lee, P. C. \& Lebenthal, E. (1986). American Journal of Physiology 250, G594-G597.

Lowry, O. H., Rosenbrough, W. J., Farr, A. L. \& Randall, R. J. (1951). Journal of Biological Chemistry 193, 265-275.

MacLeod, E. P., Derbenwick, J. P. \& Snook, J. T. (1972). Journal of Nutrition 102, 469-478.

Marchis Mouren, G. (1965). Bulletin de la Société de Chimie Biologique 47, 2207-2217. 
British Journal of Nutrition, Vol. 60, No. 3

Plate 1

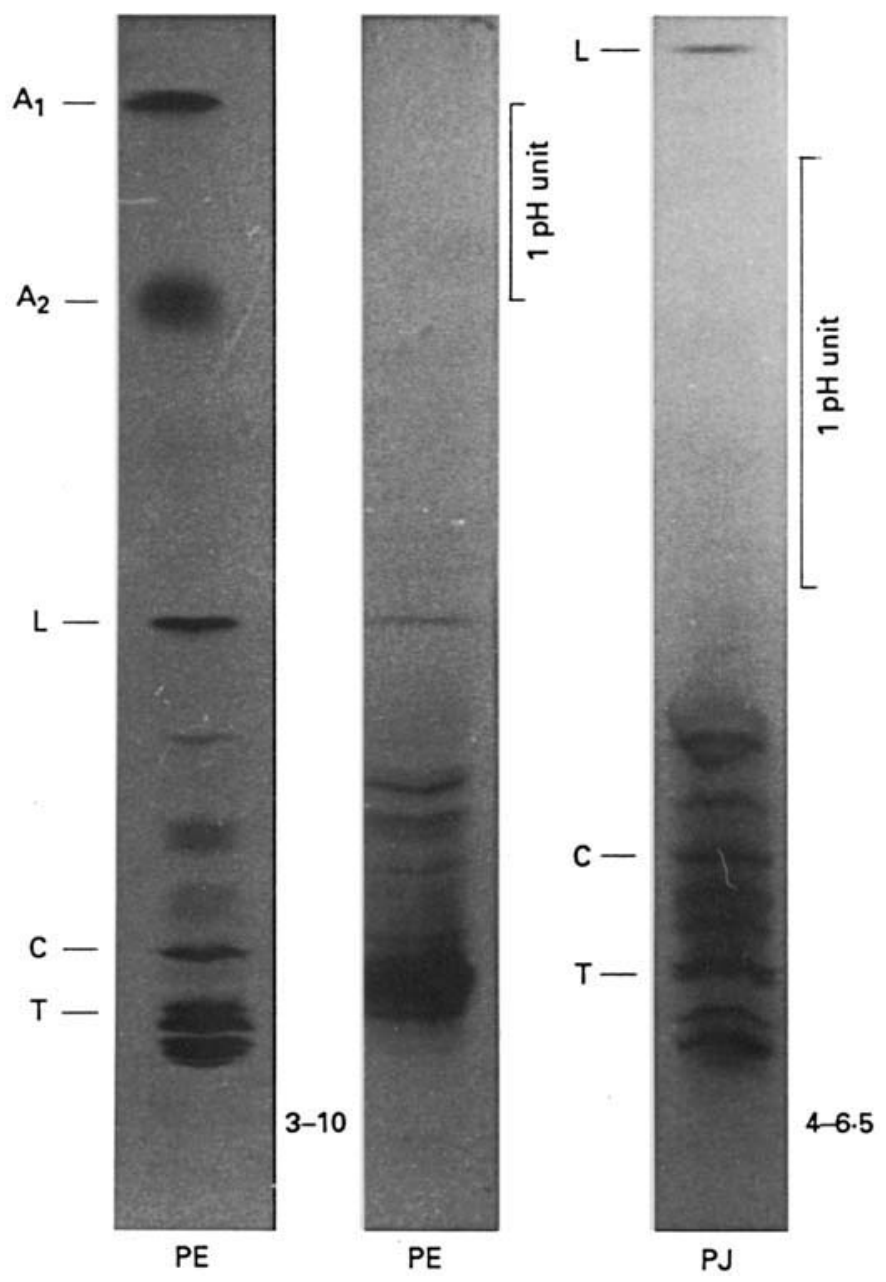


Moore, P. A. (1980). Analytical Biochemistry 108, 151-155.

Palade, G. E. (1975). Science 189, 247-258.

Prost, J. \& Belleville, J. (1987). Journal de Physiologie 349, 53A.

Prost, J., Belleville, J. \& Bouziane, M. (1982). Bulletin de la Société de Biologie 175, 690-699.

Prost, J., Belleville, J. \& Bouziane, M. (1983). Bulletin de la Société de Biologie 177, 488-502.

Robberecht, P., Cremer, M. \& Christophe, J. (1977). Gastroenterology 72, 417-420.

Rothman, S. S. \& Isenman, L. D. (1974). American Journal of Physiology 226, 1082-1087.

Saraux, B., Girard-Globa, A., Ouagued, M. \& Vacher, D. (1982). American Journal of Physiology 243, G10-G15.

Scheele, G. \& Palade, G. E. (1975). Journal of Biological Chemistry 250, 2660-2670.

Schick, J., Verspohl, R., Kern, H. \& Scheele, G. (1984). American Journal of Physiology 247, G611-G616.

Simoes-Nunes, C., Corring, T. \& Chayvialle, J. A. (1981). Reproduction, Nutrition, Développement $21,809$.

Street, H. V. \& Close, J. R. (1956). Clinica Chimica Acta 1, 256-268.

Uriel, J. (1971). In Method of Immunochemistry, vol. 3, pp. 294-321. [C. A. Williams and M. W. Chase, editors]. New York and London: Academic Press.

Van Nest, G. A., MacDonald, R. J., Raman, R. K. \& Rutter, W. J. (1980). Journal of Cell Biology 87, 784-794.

Watanabe, T., Ogasavara, N., Goto, H. \& Yamada, Y. (1980). Febs Letters 121, 369-371.

Waterlow, J. C. (1975). In Protein-Calorie Malnutrition, pp. 23-25. [R. E. Olson, editor]. New York and San Francisco: Academic Press.

Wicker, C., Puigserver, A. \& Scheele, G. (1984). European Journal of Biochemistry 139, 381-387.

EXPLANATION OF PLATE

Plate 1. Typical isoelectric focussing (IEF) bands for pancreatic juice (PJ) and pancreatic extract (PE) in a pH gradient 3-10. Typical IEF of PE band in a pH gradient $4-6.5$. Isoelectric points: amylase $(E C 3.2 .1 .1), \mathrm{A}_{1}, 8.60$ and $\mathrm{A}_{2}, 8 \cdot 20$; lipase $(E C 3.1 .1 .3), \mathrm{L}, 6 \cdot 80$; chymotrypsinogen $1(E C 3.4 .21 .1), \mathrm{C}, 5 \cdot 30$; trypsinogen $2(E C 3.4 .21 .4)$, T, 5.95 